\title{
OPTIMAL HYDRAULIC DESCALING
}

\author{
Michal POHANKA, Petr KOTRBÁČEK, Ondřej RESL, Hana BELLEROVÁ \\ Heat Transfer and Fluid Flow Laboratory, Brno University of Technology, Brno, Czech Republic, \\ michal.pohanka@vut.cz
}

https://doi.org/10.37904/metal.2020.3452

\begin{abstract}
Hydraulic descaling is an inherent part of the hot rolling process but can sometimes also be applied in the heat treatment process, continuous casting and other processes. The need for optimal descaling is linked with the quality of the final product. The goal is usually simplified to the complete removal of the scale layer from the hot surface. The descaled surfaces are often wide and a number of nozzles must be used. The quality problems are almost exclusively connected with the overlap of water jets. An experimental study of overlap optimization is presented in this paper. A new approach using in-line configuration of jets is introduced and discussed. This paper also describes why even the completely oxide-free surface achieved after descaling the unit can be a far from optimal solution. Thermal strips on the hot surface cause much more intensive oxidation of the hot part and much slower oxidation in the cold strips on the descaled surface. The speed of oxide formation on the steel surface is exponentially dependent on the surface temperature. Temperature nonhomogeneity after descaling in the rolling process can cause the same defects on the surface of the final product as poor descaling. Temperature aspects with links to heat loss and secondary oxidation are discussed.
\end{abstract}

Keywords: Descaling, hydraulic, nozzle, hot rolling, overlap

\section{INTRODUCTION}

Hydraulic descaling is essential to obtain high-quality hot-rolled steel. Scales on the surface of the rolled material are removed by a water jet and washed away [1,2]. As a multifactor process, descaling conditions can vary significantly. The most crucial factors that affect the process can be divided into mechanical effects and thermal effects $[3,4]$. The dominant parameter is impact pressure, influencing both mechanical and thermal action [5,6]. The impact pressure depends on nozzle feeding pressure, nozzle quality and nozzle standoff from the descaled surface [7-9]. For descaling purposes the following parameters must be studied: impact distribution along the spray angle of a single nozzle and impact distribution in an overlap area, where there is interaction of jets from neighboring nozzles [10].

The water jet causes thermal shock on the surface $[11,12]$ and plays a key role in crack formation in the layer of scales. The cooling intensity can be quantified by a heat transfer coefficient. Published models of hot rolling based on experimental data operate with a variable value of heat transfer coefficient in the section where the jet directly sprays the surface. The values reported in [13] vary from several hundred $\mathrm{W} \cdot \mathrm{m}^{-2} \cdot \mathrm{K}^{-1}$ to $20920 \mathrm{~W} \cdot \mathrm{m}^{-2} \cdot \mathrm{K}^{-1}$. Article [14] states that the heat transfer coefficient is a linear function of the impact pressure of the water jet and the values vary in range from $290000 \mathrm{~W} \cdot \mathrm{m}^{-2} \cdot \mathrm{K}^{-1}$ to $420000 \mathrm{~W} \cdot \mathrm{m}^{-2} \cdot \mathrm{K}^{-1}$ for impact pressures in the range $0.48 \mathrm{MPa}$ to $0.8 \mathrm{MPa}$. The authors of the paper [15] measured heat transfer coefficient values under flat jet nozzles and it was found that cooling intensity does not increase linearly with pressure, but some saturation can be observed at high pressures. This finding is consistent with the statement that a maximum possible heat transfer coefficient value exists for forced convection and convection with phase change [16]. The heat transfer coefficient is also a function of surface temperature during water cooling and the increase in water pressure also raises the Leidenfrost temperature [17]. The situation during descaling can be even more 
complex when the authors consider the presence of oxides on the surface $[18,19]$ and surface roughness [20] when studying heat transfer. As has been illustrated, due to the complexity of the process, the outcomes of experiments cover a very wide range of values.

There are some parameters which can play only a minor role but should be considered in the design of the descaling unit [21]. Thermal losses are a limiting factor for some technologies [22]. The velocity of the descaled surface has a major effect on thermal losses during descaling; this is described in [23]. The Korean company POSCO studied the possibility of modifying thermal losses by modifying the water temperature; the results of this interesting study are published in [24].

This study presents experimental methods which can help us to design the descaling units correctly. Experience from industry indicates that the main problems are in the geometrical configuration of nozzles. In other words, designing the descaling unit with a proper spray overlap is difficult [25]. An experimental study confirmed that having neighboring jets which collide with each other can significantly reduce descaling performance [10] and significantly increase cooling [4]. Industrial descaling units usually have nozzles rotated by offset angle $\beta$ set to $15^{\circ}$ (see Figure 1 right) to avoid the water jets colliding before the water hits the descaled surface $[5,7,25-32]$. The only exception are patents $[33,34]$ where the offset angle is set to $0^{\circ}$ but the configurations produce two discontinuous lines trying to avoid problem in overlap area. Study of the overlap area in the author's laboratory led to the idea of an in-line nozzle configuration which has been successfully tested in industry and is introduced in this paper and compared with classical configuration using several types of laboratory measurements.

\section{LABORATORY MEASUREMENTS}

Laboratory measurements provide information about the magnitude of impact pressure caused by water jets from descaling nozzles hitting the descaled surface, and also about impact distribution, heat transfer from the descaled surface and surface quality after descaling.

Figure 1 shows a diagram of impact pressure distribution measurements. The important feature of the device is that the impact is measured by a sensor embedded in a flat plate. Only this approach allows us to study interaction of sprays in the overlap area where the deflected water jet can significantly influence the jet from the neighboring nozzle. Examples of these measurements are shown in Figure 2.
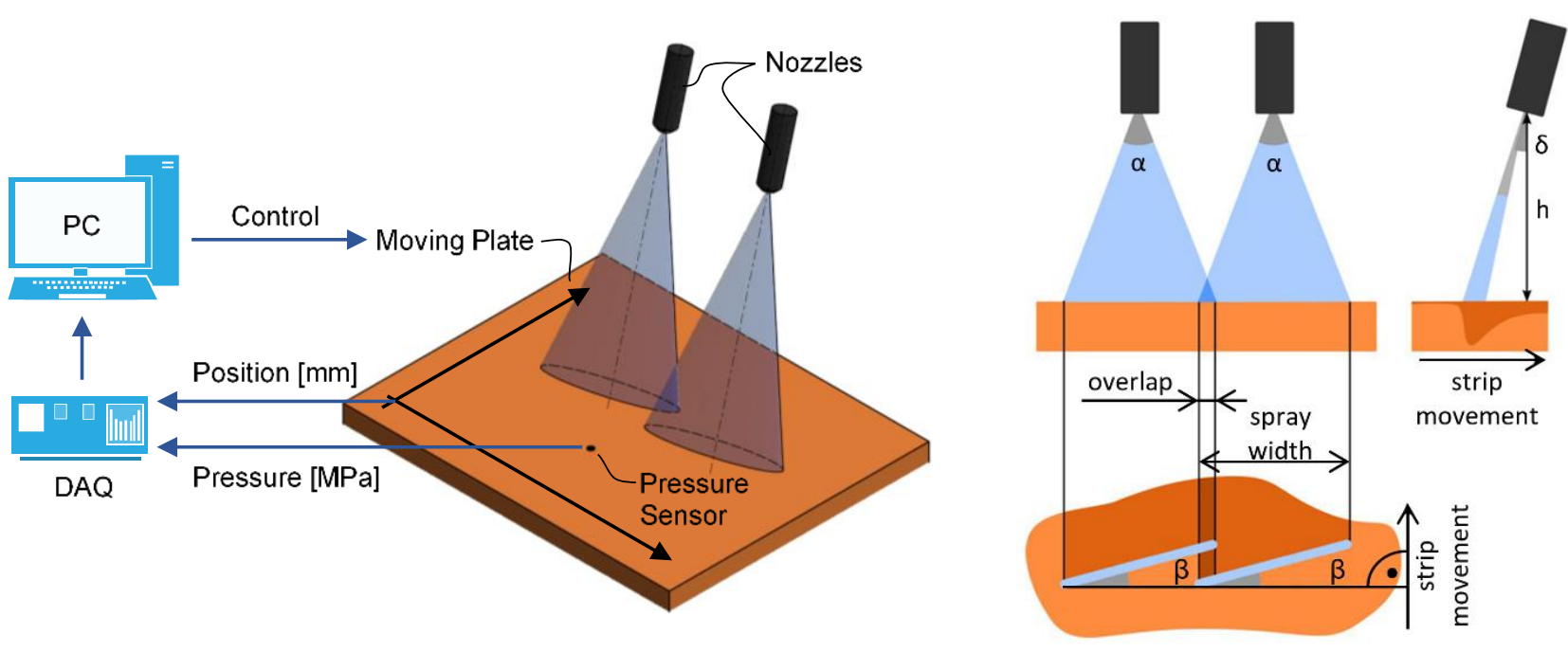

Figure 1 Diagram of impact pressure distribution measurement (left); diagram of nozzle configuration (right) 

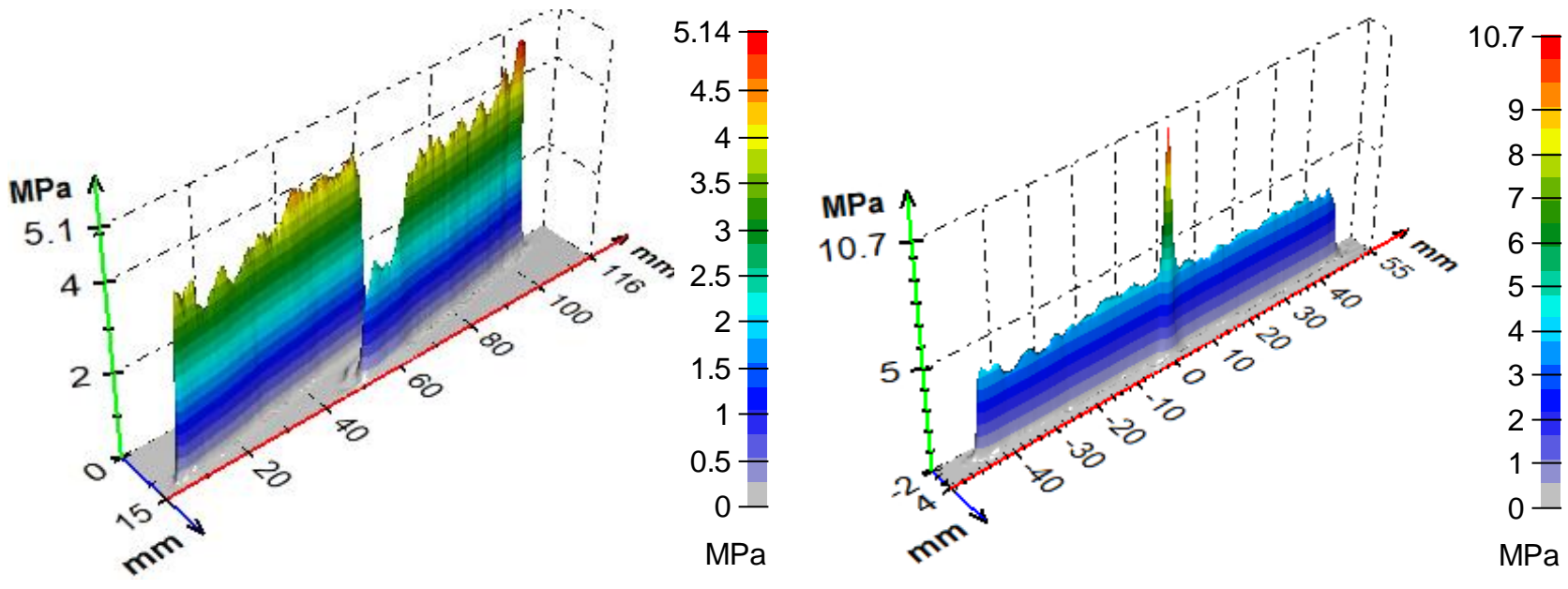

Figure 2 Impact pressure distribution measurement of two configurations: left is with offset angle $\beta=15^{\circ}$ (standard configuration) and right is with offset angle $\beta=0^{\circ}$ (in-line configuration)

The effect of the impact of the water can also be studied through erosion tests. Industry commonly uses painted steel plates to check descaling systems. Erosion tests use aluminum plates or plastic materials. The examples shown in Figure $\mathbf{3}$ are for tests with movement of the tested surface and for static tests. Static erosion tests are not suitable for study of the overlap area because the water jet digs a slit in the plate and the direction of the reflected water in the test is different to the direction of the water in the rolling plant, where it has a flat surface.

Heat transfer measurements are done using a hot moving test plate manufactured from heat resistant austenitic stainless steel to protect the surface from severe oxidation. The velocity of movement is identical to the velocity in the studied rolling plant. Details can be found in [15]. Figure 4 shows a very instructive picture of the hot steel plate after being run under two descaling jets. It is evident that the overlap area is subcooled, and the cold strip is visible on the surface. The right part of Figure 4 shows the measured variations of surface temperature across the width of the surface using an infrared line-scanner placed $0.5 \mathrm{~m}$ beyond descaling. To study the heat loss during hydraulic descaling, the hot test plate is equipped with thermocouples (see left diagram in Figure 5), which are located $0.6 \mathrm{~mm}$ below the descaled surface [4]. Distributions of heat transfer coefficients are computed for each position of the thermocouple (see right graph in Figure 5) from the recorded temperature history during the descaling experiment using inverse computation [35]. Lines T1 and T3 are plotted for the area near nozzle axis and lines T2 for the overlap area.

The last type of experiment used in the study of descaling is test of descaling quality [36,37]. The test plate is typically heated with the surface protected against oxidation. The heated plate is first exposed to the oxidation


Figure 3 Aluminum plates after erosion tests: the left picture is for a configuration with offset angle $\beta=15^{\circ}$ after the erosion test with a moving sample (black lines represent the spray width of each nozzle); the right picture is for an in-line configuration with offset angle $\beta=0^{\circ}$ (the upper eroded line shows values after a steady erosion test, while the lower area show a values after an erosion test with a moving sample) 

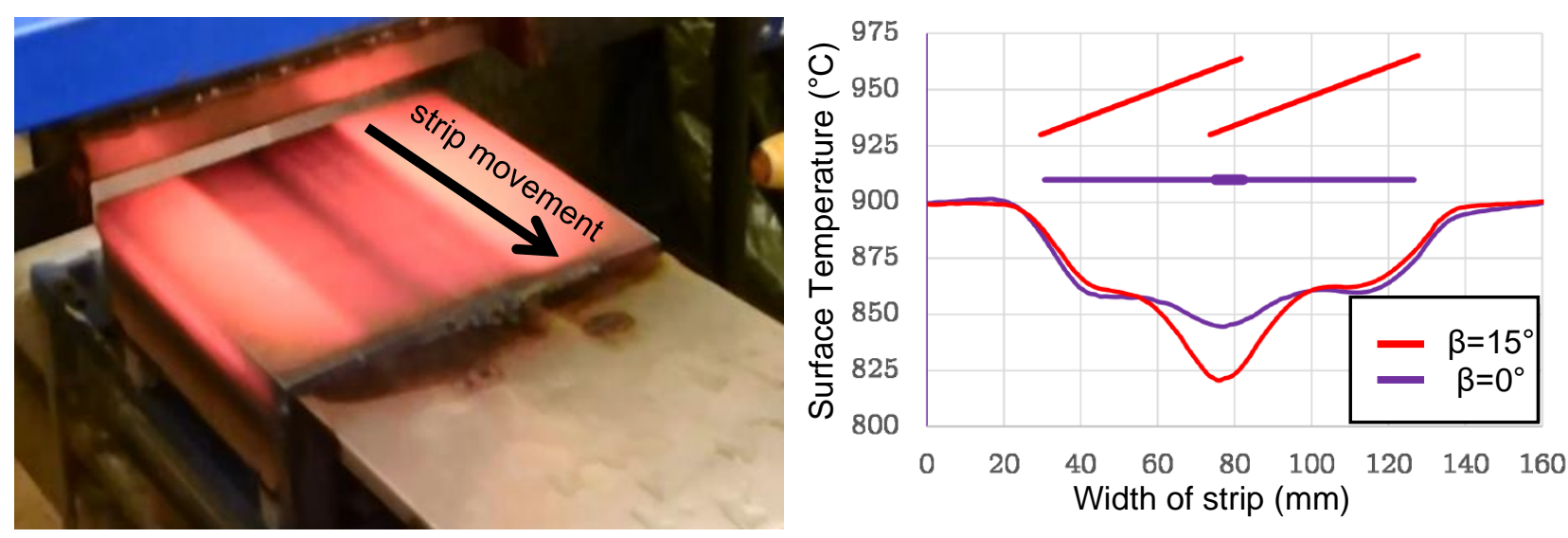

Figure 4 Cooling homogeneity measurements with two nozzles: thermal lines after passing under two descaling nozzles (left photo); measured variations of surface temperature and the sprayed area shown schematically with straight lines in the upper part of the graph (right graph)

for a defined time and then run under the descaling nozzles at the prescribed velocity. Immediately after descaling, the test plate is cooled in a box with a protective atmosphere to protect the surface from further oxidation. Finally, the thickness of the remaining scales is measured after descaling. Examples of the test plates after descaling tests are shown in Figure 6. Nozzle arrangements are illustrated by the jets' footprints from the impact pressure distribution measurements.

\section{RESULTS - COMPARISON OF STANDARD AND IN-LINE CONFIGURATIONS}

The most common configuration (standard configuration) of nozzles in a hydraulic descaling unit for flat products is shown in Figure 1 in the right diagram. The offset angle $\beta$ is usually $15^{\circ}$. The new in-line configuration has the offset angle $\beta$ set to $0^{\circ}$. The nozzles used for laboratory experiments have a catalogue spray angle of $30^{\circ}$, a water flow rate of $36 \mathrm{l} / \mathrm{min}$ for water pressure of $40 \mathrm{MPa}$, and the standoff was $75 \mathrm{~mm}$.

The results from impact pressure distribution measurements of these two configurations (standard and in-line) are presented in Figure 2. It can be observed that the left nozzle has a relatively homogeneous impact pressure distribution, but the right nozzle has low impact values in the overlap area. This is caused by the water deflecting from the left nozzle into the jet of right nozzle. On the other hand, maximum impact pressure is obtained in the overlap area for the in-line configuration. The peak pressure is twice as high as impact pressure under a single nozzle.
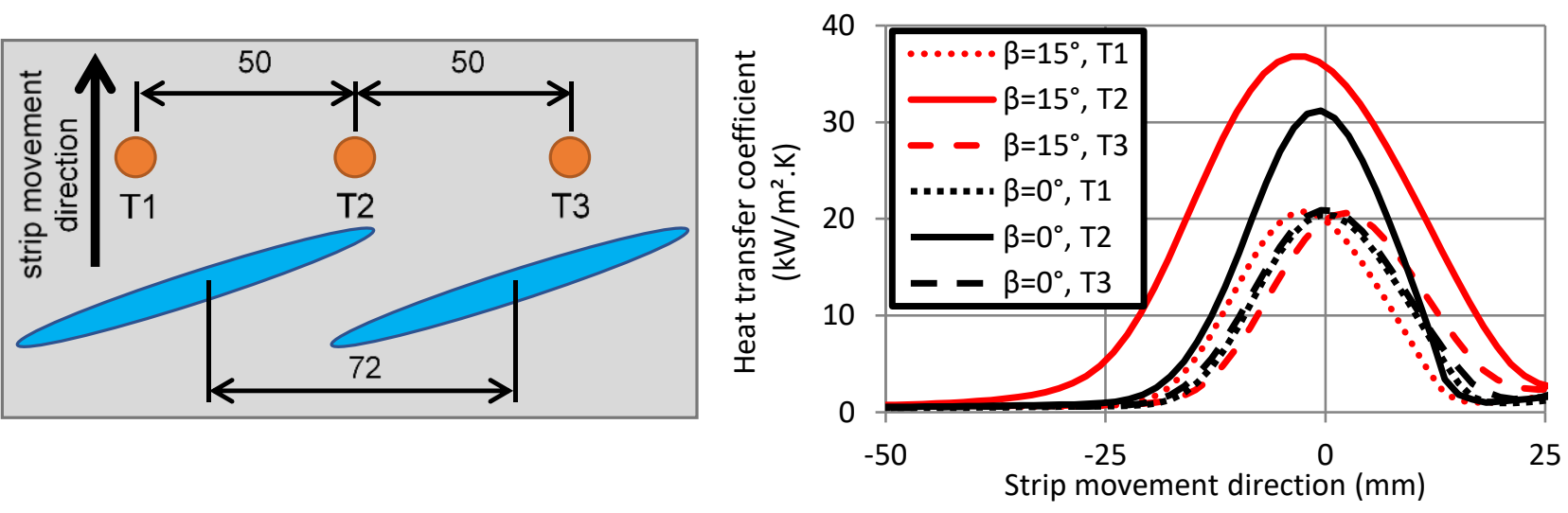

Figure 5 Heat transfer measurements of two spraying nozzles on a moving surface: thermocouple positions (T1, T2, and T3) and impact footprint of sprays for configuration with offset angle $\beta=15^{\circ}$ (left picture); measured heat transfer coefficients for two configurations: offset angle $\beta=15^{\circ}$ and $\beta=0^{\circ}$ (right graph) 
The collision between the deflected water and the impacting jet has a significant effect on the quality of hydraulic descaling near the overlap area. The erosion test with a moving plate shown in Figure 3 (left photo) clearly documents the area where there is no erosion (washout area). The nozzle's footprints in the impact area are shown by the black lines in Figure 3. No washout area was observed in the in-line configuration (Figure 3, right photo).

The negative effect of the deflected water in the washout area was confirmed by hot descaling tests for the standard configuration (see Figure 6, left photo). The remaining scales here are significantly thicker (12$28 \mu \mathrm{m})$ than in the normal area $(3-10 \mu \mathrm{m})$. Surprisingly, the most descaled area is the overlap area. The in-line configuration does not produce any washout areas and the thickness of the scales is uniform across the strip.

The quality defect in the overlap area described above is not the only problem that can be found in the rolling plant. Let us assume that the surface is perfectly clean after descaling. This fact does not mean that rolling is free of scale-induced problems. Figure 3 (left photo) shows how non-homogeneous the surface temperature can be after descaling. The dark strip in the overlap area indicates a much lower temperature. Figure 4 (right graph) shows how significant the decrease in surface temperature caused by descaling nozzles is and how significantly different the temperature in the overlap area and in the area near nozzle axis is. Heat transfer measurements (see Figure 5) confirm that the heat transfer coefficient is much higher in the overlap area (T2 curve) for standard configuration with offset angle $\beta=15^{\circ}$. The situation is much better for in-line configuration. The heat transfer coefficient is lower and significantly narrower when comparing " $\beta=0^{\circ}$, T2" with " $\beta=15^{\circ}$, T2". The lower heat transfer coefficient results in reduced heat loss during descaling and the temperature profile is more homogeneous for the in-line configuration with the offset angle $\beta=0^{\circ}$ (see Figure 4, right graph). Oxidation starts immediately on the clean hot steel surface. Because scale growth rate depends exponentially on the surface temperature, steel with strips that have both thick and thin scales enter the rolling mill and result is often visible in the surface quality when the cooling is not homogeneous across the strip.
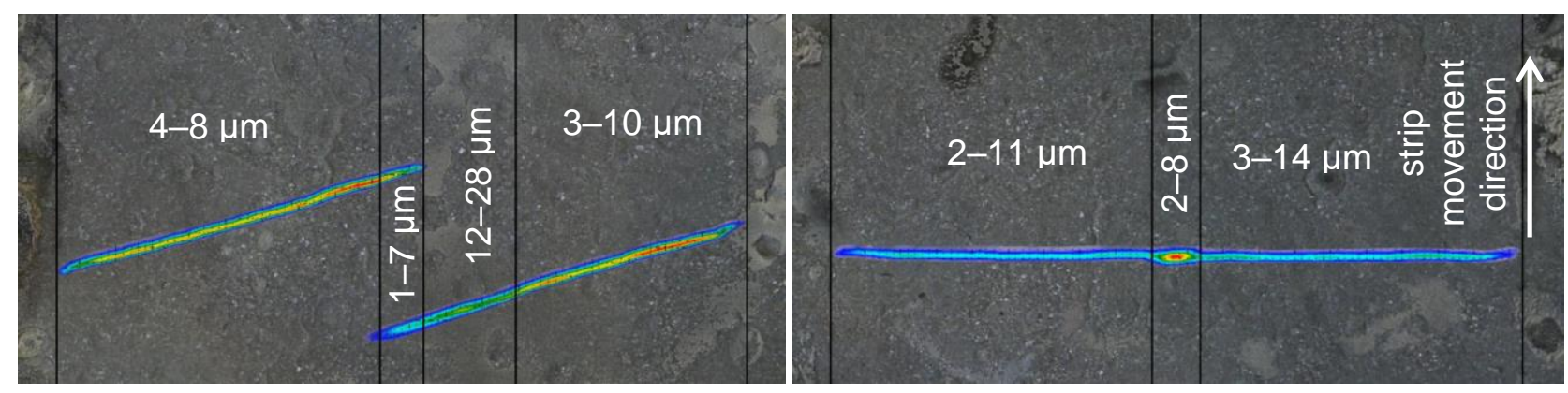

Figure 6 Descaling measurements - thickness of remaining scales: configuration with offset angle $\beta=15^{\circ}$ (left picture); in-line configuration with offset angle $\beta=0^{\circ}$ (right picture)


Figure 7 Descaling header for use in industry (manufactured by SIGMA DIZ) 
Based on the obtained results, a new type of high-pressure spray collector was designed by Brno University of Technology and SIGMA DIZ (see Figure 7), which is currently being tested in the company Liberty Ostrava a.s. in Steckel rolling mill. The obtained results are very positive, and the company wants to install new descaling headers with the in-line configuration instead of the standard descaling unit.

\section{CONCLUSION}

The problems mentioned with overlap cannot be completely eliminated but should be minimized. Testing of the in-line nozzle configuration was motivated by simultaneous optimization of impact and heat transfer. The laboratory measurements confirmed that the negative effect of interaction between deflected water and water jets from the nozzles is more significant for standard descaling configuration with an offset angle $\beta=15^{\circ}$ than for in-line configuration with an offset angle $\beta=0^{\circ}$. The experiments also showed that the most problematic area is the washout area and not the overlap area when the descaling unit uses a standard configuration. The positive aspects of in-line configuration were verified in industrial conditions.

\section{ACKNOWLEDGEMENTS}

The authors greatly appreciate the help of the SIGMA GROUP and its subsidiary SIGMA DIZproducers of descaling pumps and descaling systems- for the installation and industrial testing of the in-line descaling system in the Liberty Ostrava a.s. plant.

\section{A new descaling header was created within the project "Progressive high-pressure hydraulic systems for heavy industry" CZ.01.1.02 / 0.0 / 0.0 / 15 019/0004924.}

\section{REFERENCES}

[1] ZHANG, M., LIU, B., GRENIER, C., MONTMITONNET, P., PICARD, M., BOREAN, J.-L. Oxide fracture mechanisms in descaling of steel strips on the hot strip mill. In AIP Conference Proceedings. 2011, vol. 1353, issue 1, pp. 377-382, doi: 10.1063/1.3589537.

[2] FRICK, J.W. Audits of existing hydro mechanical descaling systems in hot rolling mills as a method to enhance product quality. In AISTech - Iron and Steel Technology Conference Proceedings. 2005, vol. 2, pp. 425-436.

[3] HLAVÁČ, L. M. Application of water jet description on the de-scaling process. International Journal of Advanced Manufacturing Technology. 2015, vol. 80, issue 5-8, pp. 721-735, doi: 10.1007/s00170-015-7020-7.

[4] POHANKA, M., VOTAVOVÁ, H. Overcooling in overlap areas during hydraulic descaling. Materiali in tehnologije. 2016, vol. 50, issue 4, pp. 575-578, doi: 10.17222/mit.2015.164.

[5] KIM, S.C., CHOI, J.W., CHOI, J.W. Method of setting nozzle intervals at the finishing scale breaker. KSME International Journal. 2003, vol. 17, issue 6, pp. 870-878, doi: 10.1007/BF02983401.

[6] BOHÁČEK, J., HORÁK, A. Numerical study of droplet dynamics impinging onto steel plate covered with scale layer. Frontiers of Mechanical Engineering in China. 2010, vol. 5, issue 4, pp. 389-398, doi: 10.1007/s11465-0100108-8.

[7] FARRUGIA, D., RICHARDSON, A., LAN, Y. Advancement in understanding of descalability during high pressure descaling. In Key Engineering Materials. 2014, vol. 622-623, pp. 29-36, DOI: 10.4028/www.scientific.net/KEM.622-623.29.

[8] MA, F., YANG, N., LIU, Y. Design of high-pressure waterjet descaling nozzles testing system with LabVIEW. In Advanced Materials Research. 2011, vol. 422, pp. 333-337, doi: 10.4028/www.scientific.net/AMR.422.333.

[9] ROBB, L. Effect of spray height, lead angle and offset angle on impact. In AISTech - Iron and Steel Technology Conference Proceedings. 2005, vol. 2, pp. 449-456.

[10] VOTAVOVÁ, H., POHANKA, M. Study of water jet collision of high pressure flat jet nozzles for hydraulic descaling. Applied Mechanics and Materials. 2016, vol. 821, pp.152-158, doi:

10.4028/www.scientific.net/AMM.821.152. 
[11] ČARNOGURSKÁ, M., PŘíHODA, M., HAJKR, Z., PYSZKO, R., TOMAN, Z. Thermal effects of a high-pressure spray descaling process. Materiali in Tehnologije. 2014, vol. 48, issue 3, pp. 389-394.

[12] FARRUGIA, D., FEDORCIUC-ONISA, C., STEER, M. Investigation into mechanisms of heat losses and mechanical descalability during high pressure water descaling. In 12th, International conference on metal forming; Metal forming 2008. Ostrava: TANGER, 2008, pp. 397-402.

[13] HOLLANDER, F. A model to calculate the complete temperature distribution in steel during hot rolling. The Journal of the Iron and Steel Institute. 1970, vol. 208, pp. 46-74.

[14] CHOI, J.W., CHOI, J.W. Convective heat transfer coefficient for high pressure water jet. ISIJ International. 2002, vol. 42, issue 3, pp. 283-289, doi: 10.2355/isijinternational.42.283.

[15] HORSKÝ, J., RAUDENSKÝ, M., POHANKA, M. Experimental study of heat transfer in hot rolling and continuous casting. In Materials Science Forum. 2005, vol. 473-474, pp. 347-354, doi: 10.4028/www.scientific.net/MSF.473474.347.

[16] BeRGMAN, T. L., LAVINE, A. S., INCROPERA, F. P., DEWITT, D. P. Fundamentals of Heat and Mass Transfer, 7th Edition. John Wiley \& Sons, 2011.

[17] HNÍZDIL, M., CHABIČOVSKÝ, M., RAUDENSKÝ, M. Influence of the impact angle and pressure on the spray cooling of vertically moving hot steel surfaces. Materiali in Tehnologije. 2015, vol. 49, issue 3, pp. 333-336, doi: 10.17222/mit.2013.239.

[18] KRZYZANOWSKI, M., BEYNON, J.H. Modelling the boundary conditions for thermo-mechanical processing-oxide scale behaviour and composition effects. Modelling and Simulation in Materials Science and Engineering. 2000, vol. 8, issue 6, pp. 927-945, doi: 10.1088/0965-0393/8/6/312.

[19] RAUDENSKÝ, M., CHABIČOVSKÝ, M., HRABOVSKÝ, J. Impact of oxide scale on heat treatment of steels. In METAL 2014 - 23rd International Conference on Metallurgy and Materials. Ostrava: TANGER, 2014, pp. 553558.

[20] BROŽOVÁ, T., CHABIČOVSKÝ, M., HORSKÝ, J. Influence of the surface roughness on the cooling intensity during spray cooling. In METAL 2016 - 25th Anniversary International Conference on Metallurgy and Material. Ostrava: TANGER, 2016, pp. 41-46.

[21] PETERSON, L. Maximizing impact force from descale headers using CFD analysis. Iron and Steel Technology. 2016, vol. 13, issue 11, pp. 50-54.

[22] DA CUNHA, M.A., PAOLINELLI, S.C. Effect of hot rolling temperature on the structure and magnetic properties of high permeability non-oriented silicon steel. Steel Research International. 2005, vol. 76, issue 6, pp. 421-425, doi: 10.1002/srin.200506031.

[23] VOTAVOVÁ, H., POHANKA, M. Effect of the speed of feedstock on heat transfer coefficient during descaling in hot rolling. In METAL 2017 - 26th International Conference on Metallurgy and Materials. Ostrava: TANGER, 2017, pp. 567-572.

[24] POHANKA, M., VOTAVOVÁ, H., RAUDENSKÝ, M., HWANG, J. Y., YOU, J. W., LEE, S. H. The effect of water temperature on cooling during high pressure water descaling. Thermal Science. 2017, vol. 22, issue 6, pp. 29652971, doi: 10.2298/TSCI160209163P.

[25] MATTHEWS, D., HVIID, L., FARRUGIA, D., YATES, P., HIJNE, F. Optimizing hydraulic descaler performance through improved monitoring and maintenance. Iron and Steel Technology. 2013, vol. 10, issue 9, pp. 80-88.

[26] FRICK, J.W. Enhanced accuracy of descaling nozzle arrangements with new, complementary measurement methods. In AISTech - Iron and Steel Technology Conference Proceedings. 2014, vol. 2, pp. 2025-2028.

[27] SPEICHER, K., STEINBOECK, A., WILD, D., KIEFER, T., KUGI, A. An integrated thermal model of hot rolling. Mathematical and Computer Modelling of Dynamical Systems. 2014, vol. 20, issue 1, pp. 66-86, doi: 10.1080/13873954.2013.809364.

[28] FRICK, J.W. Optimisation of technologies for hydro-mechanical descaling of steel. Revue de Metallurgie. Cahiers D'Informations Techniques. 2009, vol. 106, issue 2, pp. 60-68, doi: 10.1051/metal/2009015.

[29] KERMANPUR, A., EBNONNASIR, A., YEGANEH, A.R.K., IZADI, J. Artificial neural network modeling of high pressure descaling operation in hot strip rolling of steels. ISIJ International. 2008, vol. 48, issue 7, pp. 963-970, doi: 10.2355/isijinternational.48.963. 
[30] RAMÍREZ-CUELLAR, J., GUERRERO-MATA, M.P., LEDUC, L.A., COLÁS, R. Modelling descaling during hot rolling of steel. In Journal De Physique. IV : JP. 2004, vol. 120, pp. 209-215, doi: 10.1051/jp4:2004120024.

[31] FRICK, J.W. More efficient hydraulic descaling header designs. MPT Metallurgical Plant and Technology International. 2004, vol. 27, issue 2, pp. 90-94.

[32] SILK, N.J. The practical aspects of hydraulic de-scaling. Steel Times International. 2001, vol. 25, issue 7, pp. 3841.

[33] NIPPON KOKAN KK - NKK CORP. Method and Device for Descaling. Japan, B21B45/08, JPH09174137A, 199707-08.

[34] CHENG PI-KUN, CHINA STEEL CORPORATION, HUANG CHAO-CHI, JU CHUNG-PING, SHIH CHUN-CHAO, TUNG KUN-CHENG. Hot rolling high-pressure fluid descaling method and descaling apparatus. US, B08B3/00, B21B45/08, US9174256B2, 2015-11-03.

[35] POHANKA, M., KOTRBÁČEK, P. Design of cooling units for heat treatment. In CZERWINSKI F. Heat treatment conventional and applications. In Tech. Rijeka, Croatia: InTech, 2012, pp. 1-20.

[36] KOTRBÁČEK, P., HORSKÝ, J., RAUDENSKÝ, M., POHANKA, M. Influence of parameters of hydraulic descaling on temperature losses and surface quality of rolled material. Steel Grips, Journal of steel and related materials. 2004, vol. 2004, no. 2, pp. 367-370.

[37] HORSKÝ, J., RAUDENSKÝ, M., VAVREČKA, L. Experimental study of hydraulic descaling. In HEFAT 2007. Sun City, South Africa, 2007, pp. 1-8. 